\title{
KARAKTERISTIK PENGGUNAAN WAKTU DAN PENGGUNAAN MODA TRANSPORTASI PADA AKTIVITAS AKHIR PEKAN DI JABODETABEK
}

\author{
Josia Marxalim ${ }^{1}$ dan Leksmono Suryo Putranto ${ }^{2}$ \\ ${ }^{1}$ Program Studi Sarjana Teknik Sipil, Universitas Tarumanagara, Jl. Letjen S. Parman No.1 Jakarta \\ Email: josia.marxalim97@gmail.com \\ ${ }^{2}$ Program Studi Sarjana Teknik Sipil, Universitas Tarumanagara, Jl. Letjen S. Parman No.1 Jakarta \\ Email: lexy_putranto@yahoo.co.id
}

\begin{abstract}
ABSTRAK
Aktivitas akhir pekan sering kali dijadikan waktu yang tepat untuk melepas beban pikiran selama sepekan. Hal tersebut dikarenakan, kita banyak menemukan masalah selama beraktivitas, baik itu di pekerjaan maupun di pendidikan. Dengan itu, aktivitas yang paling tepat untuk dilakukan pada akhir pekan ialah aktivitas fisik (olah-raga) dan juga aktivitas rekreasi. Beberapa penelitian telah menjelaskan, kepenatan yang terjadi pada setiap individu harus disalurkan ke aktivitas fisik, dan rekreasi, karena kedua aktivitas tersebut sudah terbukti memberikan afek positif pada hari senin pagi pekan berikutnya. Hal tersebut dikonfirmasi oleh responden yang telah mengisi kuesioner, mereka menjawab bahwa aktivitas fisik dan rekreasi berhasil memberikan afek positif pada diri mereka. Lalu, seseorang akan memilih kendaraan yang hendak mereka gunakan. Seperti di JABODETABEK, ojek online, taksi online, sudah mudah digunakan. Kemudian adanya Bus, dan juga KRL yang sudah saling terhubung, membuat seseorang lebih mudah dalam bermobilisasi. Akan tetapi, tidak sedikit orang yang akan menggunakan kendaraan pribadi untuk aktivitas mereka, hal tersebut berkaitan dengan jumlah orang yang akan pergi bersama, serta adanya rasa nyaman yang akan mereka terima, dan tentu dari sisi waktu, akan memangkas waktu ketimbang mereka menggunakan transportasi umum. Berdasarkan kuesioner yang sudah saya sebarkan, mayoritas menjawab menggunakan mobil bila memakai kendaraan pribadi, dan memilih ojek online bila menggunakan kendaraan umum. Kemudian aktivitas fisik yang paling sering dilakukan pada akhir pekan ialah pergi ke tempat kebugaran. Untuk aktivitas rekreasi, paling sering adalah pergi menonton bioskop, dan mayoritas mereka melakukan aktivitas tersebut pada siang hari.
\end{abstract}

Kata kunci: Aktivitas Akhir Pekan, Moda Transportasi dan JABODETABEK.

\section{PENDAHULUAN}

\section{Latar Belakang}

Akhir pekan bisa menjadi waktu yang pas untuk seseorang dapat beraktivitas fisik, melakukan perjalanan rekreasi, atau sekedar berkumpul dengan keluarga. Namun terkadang, waktu akhir pekan juga masih harus mengurus beberapa pekerjaan yang belum selesai pada hari kerja. Menurut Zhong dan Hunt (2010), Sebagian besar aktivitas akhir pekan tidak terkait dengan bersekolah dan bekerja yang kurang dari 5\% saja (30\% lebih belanja, sosial dan hiburan). Mengatur jadwal dengan baik adalah salah satu cara yang tepat untuk dapat menyempatkan diri beraktivitas fisik, melakukan perjalanan rekreasi, dll.

Hal tersebut dirasa penting karena dapat mengurangi stres atau beban pikiran setiap individu, seperti yang dikatakan oleh Feuerhahn dkk (2014). Aktivitas fisik dapat memperbaiki suasana hati dengan cara membiarkan seseorang untuk keluar sementara dari stres pekerjaan. Selain itu, hal tersebut juga dapat mendorong setiap individu untuk tidak terpaku dengan gadget mereka, karena ketergantungan dengan gadget memiliki dampak yang buruk. Seperti, kesehatan akan menurun, hubungan atau relasi dengan lingkungan juga akan merenggang, kualitas tidur tidak baik, dll.

Sport club, kemudian tempat-tempat rekreasi, akan cenderung ramai dipadati oleh para pengunjung yang hendak beraktivitas. Banyak dari mereka yang datang bersama dengan anggota keluarga lainnya, hal tersebut berdampak pada penggunaan moda transportasi yang dapat mengangkut lebih banyak orang di dalamnya. Jasa penyediaan angkutan online adalah salah satu jawaban dari masalah tersebut, seperti taksi online, dan mobil antar jemput online. Tetapi tidak sedikit, orang-orang akan membawa kendaraan sendiri, dengan alasan mereka lebih suka menyetir sendiri, banyak tempat yang akan dikunjungi, banyak teman atau kerabat yang mau menumpang, dll.

Efek dari tingkat penggunaan moda transportasi yang tinggi, akan berimbas pada volume kendaraan yang meningkat serta kemacetan yang berbanding lurus dengan volume kendaraan. 
Melalui penelitian ini, saya akan menganalisis aktivitas apa saja yang sering dilakukan oleh setiap individu, dan moda transportasi apa yang sering mereka gunakan untuk mencapai lokasi aktivitas mereka. Selain itu, saya akan meminta persepsi mereka mengenai kemacetan yang timbul pada akhir pekan serta afek positif apa yang mereka rasakan pada hari senin pagi setelah melewati akhir pekan.

\section{Batasan Masalah}

Adapun batasan-batasan di dalam penulisan penelitian ini, antara lain:

1. Wilayah yang digunakan dalam penelitian ini adalah JABODETABEK (Jakarta, Bogor, Depok, Tangerang, dan Bekasi).

2. Subjek penelitian ini merupakan individu yang berusia 17-60 tahun dan melakukan aktivitas pada akhir pekan.

\section{Rumusan Masalah}

Rumusan masalah yang dibahas :

1. Bagaimana setiap individu menggunakan waktu pada akhir pekan?

2. Bagaimana penggunaan moda transportasi pada akhir pekan?

3. Kapan waktu yang ideal untuk setiap individu beraktivitas?

4. Bagaimana hubungan aktivitas akhir pekan terhadap afek positif yang timbul pada hari senin pagi?

\section{Tujuan Penelitian}

Adapun tujuan yang ingin dicapai dalam penulisan penelitian ini:

1. Mengetahui aktivitas individu pada akhir pekan.

2. Menganalisis moda transportasi yang digunakan pada akhir pekan.

3. Menganalisis waktu yang ideal untuk melakukan aktivitas.

4. Menganalisis hubungan aktivitas akhir pekan dengan afek positif pada hari senin pagi.

\section{TINJAUAN PUSTAKA}

\section{Aktivitas Akhir Pekan}

Pada akhir pekan, utilitas penjadwalan kegiatan rekreasi untuk dilakukan dan durasi lebih panjang adalah tinggi. Ditemukan bahwa, saat akhir pekan penjadwalan aktivitas tidak diperngaruhi oleh waktu tempuh yang dibutuhkan, namun waktu tempuh yang lebih panjang biasanya berakibat pada durasi aktivitas sosial yang lebih panjang.

1. Jenis aktivitas akhir pekan: (1) Kebutuhan dasar seperti tidur, mencuci, berpakaian, berkemas, makan siang, makan malam dan sarapan (2) Bekerja/ sekolah termasuk kerja jarak jauh (telework), kerja suka-rela, pelatihan dll (3) Kewajiban rumah tangga seperti bersih-bersih, pemeliharaan, merawat anak, merawat hewan dll (4) Antar/ jemput orang, makanan, kudapan, sewa video, laundry, surat dll (5) Kegiatan belanja seperti bahan makanan, kebutuhan pribadi dll (6) Aktivitas pelayanan seperti kesehatan/ rumah sakit, perawatan diri, perbankan, keagamaan, perawatan kendaraan dll (7) Aktivitas rekreasi dan hiburan (8) Aktivitas sosial termasuk mengunjungi dan menjamu di bar/ klub, merencanakan event sosial, percakapan telepon panjang (9) Kegiatan lain (Habib, 2010).

2. Sebagian besar aktivitas akhir pekan tidak terkait dengan bersekolah dan bekerja yang kurang dari $5 \%$ saja (30\% lebih belanja, sosial dan hiburan) (Zhong dan Hunt, 2010).

3. Rumah tangga dengan lebih banyak anggota anak-anak dan memiliki lebih banyak sepeda cenderung beraktivitas di luar rumah dan melakukan rekreasi murni (Bhat dan Gossen, 2004).

4. Kegiatan akhir pekan dan perjalanan akan sangat bergantung pada fasilitas / perencanaan sistem transportasi yang baik, dan evaluasi manajemen perkotaan yang andal (Bhat dan Srinivasan, 2005).

\section{Jenis-Jenis Moda Transportasi}

Jenis moda transportasi terus berkembang dari zaman ke untuk memenuhi kebutuhan bertransportasi. Jenis-jenis transportasi yang sering digunakan pada saat ini adalah :

1. Angkutan pribadi

Angkutan pribadi (private transportation) adalah moda transportasi yang dikhususkan untuk pribadi seseorang yang bebas menggunakannya kemana saja, kapan saja, dan di mana saja yang diinginkan atau tidak menggunakannya sama sekali (Simanjuntak, 2009). 


\section{Angkutan umum}

Angkutan Umum adalah angkutan penumpang yang dilakukan dengan sistem sewa atau bayar. Termasuk dalam pengertian angkutan umum penumpang adalah: angkutan kota (bus, minibus, dsb), kereta api, angkutan air dan angkutan udara (Warpani, 1990).

3. Angkutan online

Angkutan Jalan yang berjalan dengan mengikuti serta memanfaatkan perkembangan ilmu pengetahuan (teknologi) berbasis aplikasi dan online baik untuk pemesanan maupun pembayaran, Misalnya ojek online, taxi online, dan mobil online.

\section{Hubungan Antara Aktivitas Akhir Pekan terhadap Berkurangnya Afek Negatif Senin pagi}

Kegiatan akhir pekan sering kali digunakan oleh banyak orang untuk menyalurkan hobi mereka, baik itu aktivitas fisik, aktivitas di dalam rumah, atau di luar rumah, dll. Ada kalanya beberapa orang menyalurkan hobi mereka untuk melepas penat pekerjaan / sekolah / hal-hal lain. Hubungan antara aktivitas akhir pekan terhadap berkurangnya efek negatif juga didukung oleh beberapa ahli, seperti:

1. Berkurangnya afek negatif pada senin pagi menunjukan adanya pemulihan penghilang ketegangan. Hal tersebut dirasa telah berhasil setelah adanya suatu periode istirahat (berakhir pekan) yang mengindikasikan bahwa pemulihan telah terjadi (Sonnentag \& Fritz, 2015).

2. Kegiatan fisik pada akhir pekan juga menurunkan ketegangan tubuh dengan cara merelaksasi otot dan mengurangi tingkat hormone stress seperti kortisol (Krajewski dkk, 2011).

3. Aktivitas fisik dapat memperbaiki suasana hati dengan cara membiarkan seseorang untuk keluar sementara dari stress pekerjaan (Feuerhahn dkk, 2014).

4. Menurut Sonnentag dan Fritz (2007), pilihan aktivitas waktu senggang sangat bervariasi, tapi pengalaman psikologis mendasarnya membantu seseorang untuk pulih dari kerja dan ketegangan.

\section{Car Free Day}

Demi menjaga kualitas lingkungan hidup tempat kita tinggal khususnya kesehatan udara di ibukota, dan Indonesia pada umumnya, pemerintah telah membuat berbagai kebijakan untuk menjaga lingkungan hidup. Salah satunya kegiatan Hari Bebas Kendaraan Bermotor atau yang lebih dikenal sebagai Car Free Day.

Telah ditentukan kewajiban menjaga lingkungan hidup tersebut di dalam Undang-Undang Nomor 32 Tahun 2009 Tentang Perlindungan dan Pengelolaan Lingkungan Hidup. Yang dimaksud lingkungan hidup ialah, kesatuan ruang dengan semua benda, daya, keadaan, dan makhluk hidup, termasuk manusia dan perilakunya untuk kelangsungan kehidupan dan kesejahteraan manusia serta makhluk hidup lainnya.

Untuk menindaklanjuti UU Lingkungan Hidup tersebut dan juga karena kualitas udara di ibukota telah menurun karena polusi, dalam beberapa tahun belakangan Pemprov DKI Jakarta telah membuat kegiatan Hari Bebas Kendaraan Bermotor atau Car Free Day. Secara khusus untuk mengatur kegiatan tersebut pemerintah DKI mengeluarkan Peraturan Gubernur Provinsi Daerah Khusus Ibukota Jakarta Nomor 12 Tahun 2016 Tentang Pelaksanaan Hari Bebas Kendaraan Bermotor.

Hari Bebas Kendaraan Bermotor yang selanjutnya disingkat HBKB adalah hari dimana pada suatu periode waktu tertentu kendaraan bermotor (kecuali Bus Trans Jakarta yang menggunakan Bahan Bakar Gas) tidak boleh melintasi kawasan/ruas jalan yang sudah ditetapkan sebagai lokasi pelaksanaan HBKB. Car Free Day juga berfungsi sebagai wadah kegiatan utama yaitu penutupan jalan, pengukuran kualitas udara dan kegiatan penunjang seperti olah raga, kesenian dan sosial.

\section{Karakteristik Individu pada Aktivitas Akhir Pekan}

Karakteristik mengacu kepada karakter dan gaya hidup setiap individu, serta nilai-nilai yang berkembang secara teratur sehingga tingkah laku menjadi lebih konsisten dan mudah diperhatikan (Nanda, 2013).

Selain itu, karakteristik merupakan ciri atau karateristik yang secara alamiah melekat pada diri seseorang yang meliputi umur, jenis kelamin, ras/suku, pengetahuan, agama/ kepercayaan, prinsip pribadi dan sebagainya. Adapun karakteristik pada setiap individu berkaitan dengan aktivitas akhir pekan ialah sebagai berikut:

1. Pengambilan Keputusan

Pengambilan keputusan merupakan proses untuk membuat suatu pilihan yang bersifat intensional dan reflektif dalam respon kebutuhan. Proses ini dipengaruhi masa lalu, masa sekarang dan perkiraan masa yang akan datang (Kleindorfer, 1993).

2. Keaktifan dan Kemampuan Fisik

Secara harfiah keaktifan berasal dari kata aktif yang berarti sibuk, giat Kamus Besar Bahasa Indonesia (2002). Aktif mendapat awalan kedan -an, sehingga menjadi keaktifan yang mempunyai arti kegiatan atau kesibukan. 
Dalam hal ini, aktivitas fisik pada akhir pekan berkaitan dengan aktivitas yang hendak dilakukan oleh seseorang pada akhir pekan mereka.

\section{METODOLOGI PENELITIAN}

\section{Flowchart}

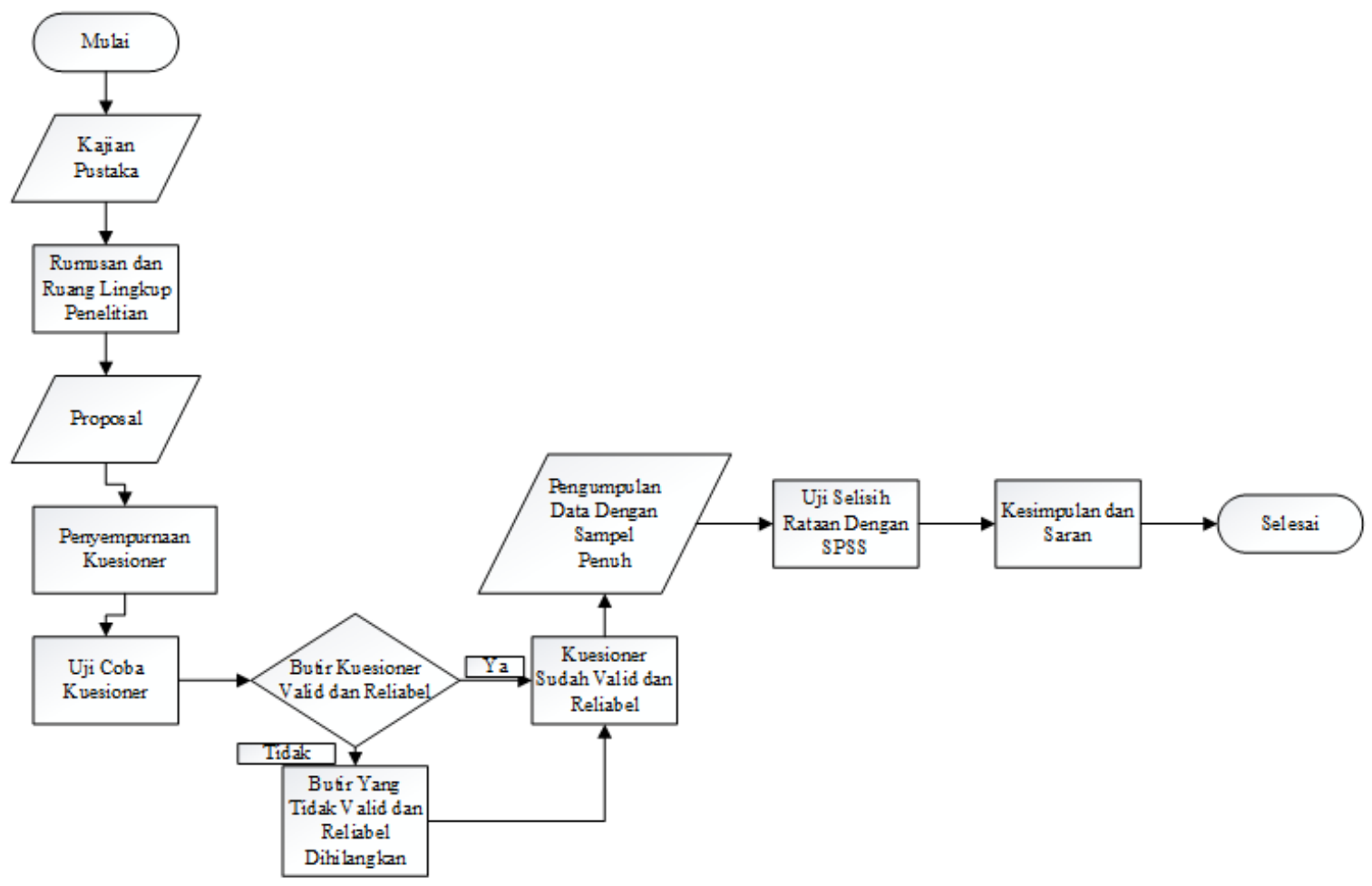

Gambar 1. Tahapan Penelitian

\section{Prosedur Penelitian}

Dalam penelitian ini digunakan dua metode kuesioner yakni online dan langsung. Kuesioner langsung dibagikan kepada 60 responden. Responden dapat langsung bertanya kepada penyurvei apabila ada butir pertanyaan yang kurang jelas. Sebanyak 95 orang mengisi melalui Google Form. Tautan untuk mengisi kuesioner tersebut dibagikan melalui email atau aplikasi seperti Whatsapp dan Line. Namun kelemahan metode kursioner online adalah responden tidak dapat langsung bertanya kepada responden.

Kuesioner bersisi 2 bagian utama yakni data umum dan butir pertanyaan. Pada data umum responden diminta untuk mengisi nama, jenis kelamin, usia, domisili sekarang, pendidikan terakhir, pekerjaan, status perkawinan, jumlah pengeluaran dalam satu bulan, agama, tinggi dan berat badan, penggunaan alat bantu penglihatan, dan penyakit khusus. Pada bagian kedua dalam penelitian ini terdapat 20 butir pertanyaan yang akan diuji. Responden diminta untuk mengisi kuesioner mengenai aktivitas yang dilakukan, menggunakan Skala Likert dimana nilai 1 hampir tidak pernah hingga nilai 4 hampir selalu. Kemudian tingkat pertimbangan saat hendak melakukan aktivitas tersebut, disini juga menggunakan Skala Likert dimana nilai 1 menunjukkan sangat tidak setuju hingga nilai 4 menunjukkan sangat setuju. Lalu kepemilikan dan penggunaan moda transportasi, serta elemen lain yang berkaitan dengan aktivitas pada akhir pekan. Berikut adalah pertanyaan-pertanyaan yang terdapat dalam kuesioner:

1. Aktivitas yang dilakukan pada aktivitas akhir pekan.

2. Pertimbangan saat hendak melakukan aktivitas.

3. Keikutsertaan dalam komunitas tertentu.

4. Lokasi melakukan aktivitas.

5. Moda transportasi yang dimiliki.

6. Moda transportasi pribadi dan umum yang digunakan untuk beraktivitas.

7. Frekuensi penggunaan kendaraan pribadi pada akhir pekan. 
8. Jarak mencapai lokasi aktivitas.

9. Durasi perjalanan untuk mencapai lokasi aktivitas.

10. Waktu saat melakukan aktivitas.

11. Waktu yag dikehendaki untuk melakukan aktivitas.

12. Lama durasi beraktivitas.

13. Waktu terakhir kali melakukan aktivitas.

14. Orang yang menemani beraktivitas.

15. Pengambilan keputusan saat hendak beraktivitas.

16. Jadwal pasti pada saat akhir pekan.

17. Pengaruh positif pada senin pagi pekan berikutnya setelah berakhir pekan.

18. Perbandingan keadaan hati pada jumat sore dengan senin pagi.

19. Kualitas tidur yang cukup.

20. Perubahan fisik setelah aktivitas akhir pekan yang rutin.

Pertanyaan nomor 1-4 masuk dalam kategori karakteristik aktivitas akhir pekan. 5-9 kategori moda transportasi guna mendukung aktivitas akhir pekan. 10-14 kategori waktu penyelenggaraan aktivitas akhir pekan, dan 15-20 masuk dalam kategori elemen lain yang mempengaruhi dan mengatur aktivitas akhir pekan.

\section{DATA PENELITIAN}

Terdapat 155 responden yang berpartisipasi dalam penelitian ini. Tabel 1 menunjukkan distribusi data berdasarkan jenis kelamin dan usia responden.

Tabel 1. Distribusi Responden Berdasarkan Jenis Kelamin dan Usia Responden

\begin{tabular}{llr}
\hline $\begin{array}{c}\text { Jenis } \\
\text { kelamin }\end{array}$ & \multicolumn{1}{c}{ Usia } & $\begin{array}{c}\text { Jumlah } \\
\text { Responden }\end{array}$ \\
\hline Pria & 17-25 Tahun & 93 \\
& 26-35 Tahun & 9 \\
& $>$ 35 Tahun & 3 \\
\hline Wanita & 17-25 Tahun & 40 \\
& 26-35 Tahun & 8 \\
& $>$ 35 Tahun & 2 \\
\hline Total & & 155 \\
\hline
\end{tabular}

Sebagian besar responden berusia diantara 17-25 tahun, dan responden yang berusia lebih dari 35 tahun hanya 5 orang. Mayoritas didominasi oleh responden pria dengan total 105 orang. Dari Skala Likert mengenai kelompok aktivitas yang dilakukan pada aktivitas, didapati data sebagai berikut :

Tabel 2. Jumlah Data, Nilai Minimal, Nilai Maksimal dan Rataan Dari Hasil Aktivitas Rekreasi

\begin{tabular}{clccc}
\hline No & \multicolumn{1}{c}{ Indikator } & Min & Maks & Rataan \\
\hline 1 & Pergi ke bioskop & 1 & 4 & 2,55 \\
2 & Pergi ke museum & 1 & 3 & 1,20 \\
3 & Pergi ke tempat bersejarah & 1 & 3 & 1,16 \\
4 & Pergi mendaki gunung & 1 & 4 & 1,35 \\
5 & Pergi ke pantai & 1 & 4 & 1,70 \\
\hline
\end{tabular}

Tabel 3. Jumlah Data, Nilai Minimal, Nilai Maksimal dan Rataan Dari Hasil Aktivitas Fisik

\begin{tabular}{clccc}
\hline No & \multicolumn{1}{c}{ Indikator } & Min & Maks & Rataan \\
\hline 1 & Pergi ke tempat kebugaran & 1 & 4 & 2,11 \\
2 & Pergi ke gelanggang olah-raga & 1 & 4 & 2,10 \\
3 & Pergi bermain golf & 1 & 3 & 1,14 \\
4 & Berolah-raga ekstrem & 1 & 4 & 1,23 \\
\hline
\end{tabular}

Tabel 4. Jumlah Data, Nilai Minimal, Nilai Maksimal dan Rataan Dari Hasil Aktivitas Keagamaan

\begin{tabular}{clccc}
\hline No & \multicolumn{1}{c}{ Indikator } & Min & Maks & Rataan \\
\hline 1 & Pergi ke tempat ibadah & 1 & 4 & 3,31 \\
2 & Mengikuti pedalaman keagamaan & 1 & 4 & 1,89 \\
\hline
\end{tabular}


Tabel 5. Jumlah Data, Nilai Minimal, Nilai Maksimal dan Rataan Dari Hasil Aktivitas Sosial

\begin{tabular}{clccc}
\hline No & \multicolumn{1}{c}{ Indikator } & Min & Maks & Rataan \\
\hline 1 & Mengunjungi panti asuhan & 1 & 4 & 1,26 \\
2 & Mengunjungi panti jompo & 1 & 3 & 1,16 \\
3 & Melakukan pengobatan gratis & 1 & 3 & 1,20 \\
4 & Pergi live in ke pedesaan & 1 & 3 & 1,23 \\
\hline
\end{tabular}

Tabel 6. Jumlah Data, Nilai Minimal, Nilai Maksimal dan Rataan Dari Hasil Aktivitas Pendidikan

\begin{tabular}{clccc}
\hline No & \multicolumn{1}{c}{ Indikator } & Min & Maks & Rataan \\
\hline 1 & Pergi ke kampus & 1 & 4 & 2,05 \\
2 & Pergi ke sekolah & 1 & 4 & 1,27 \\
3 & Pergi ke tempat kursus & 1 & 4 & 1,35 \\
\hline
\end{tabular}

Tabel 7. Jumlah Data, Nilai Minimal, Nilai Maksimal dan Rataan Dari Hasil Aktivitas Pekerjaan

\begin{tabular}{clccc}
\hline No & \multicolumn{1}{c}{ Indikator } & Min & Maks & Rataan \\
\hline 1 & Pergi ke kantor/pabrik/gudang/proyek & 1 & 4 & 1,89 \\
2 & Pergi bertemu client & 1 & 4 & 1,59 \\
3 & Pergi menghadiri seminar & 1 & 4 & 1,73 \\
4 & Pergi mengurus surat birokrasi negara & 1 & 4 & 1,22 \\
5 & Pergi berbelanja & 1 & 4 & 1,88 \\
\hline
\end{tabular}

Tabel 8. Jumlah Data, Nilai Minimal, Nilai Maksimal dan Rataan Dari Hasil Aktivitas Rumah

\begin{tabular}{clccc}
\hline No & Indikator & Min & Maks & Rataan \\
\hline 1 & Tidur & 1 & 4 & 3,19 \\
2 & Membaca & 1 & 4 & 2,29 \\
3 & Bermain games & 1 & 4 & 2,73 \\
4 & Berinternet & 2 & 4 & 3,47 \\
5 & Menonton TV & 1 & 4 & 3,09 \\
6 & Menonton Video & 1 & 4 & 3,34 \\
7 & Bertelefon & 1 & 4 & 2,64 \\
8 & Mengurus anak & 1 & 3 & 1,15 \\
9 & Mengurus rumah & 1 & 4 & 1,99 \\
10 & Mengurus kendaraan & 1 & 4 & 1,93 \\
\hline
\end{tabular}

\section{ANALISIS DAN PEMBAHASAN}

Berdasarkan dari setiap kelompok aktivitas, terdapat aktivitas yang paling sering dilakukan. Aktivitas rekreasi, pergi ke bioskop dengan rataan 2,55. Aktivitas fisik, pergi ke tempat kebugaran dengan rataan 2,11. Aktivitas keagamaan, pergi ke tempat ibadah dengan rataan 3,31. Aktivitas sosial, pergi ke panti asuhan dengan rataan 1,26. Aktivitas pendidikan, pergi ke kampus dengan rataan 2,05. Aktivitas pekerjaan, pergi ke kantor/pabrik dengan rataan 1.89. Serta aktivitas rumah, adalah berinternet dengan rataan 3,47.

Dengan hasil diatas, dapat dilihat bahwa, setiap individu lebih tertarik dengan aktivitas di dalam rumah dan aktivitas rekreasi, karena memiliki rataan tertinggi pertama dan kedua. Sedangkan, aktivitas yang paling jarang dilakukan pada aktivitas akir pekan ialah aktivitas sosial, meskipun nilai maksimum mencapai 4 , tetapi hanya sedikit orang yang melakukan aktivitas sosial setiap akhir pekan.

Kemudian, berdasarkan jawaban responden, aktivitas yang memberikan afek positif untuk pekan berikutnya adalah aktivitas fisik dan rekreasi. Hal tersebut membuktikan apa yang dikatakan oleh Krajewski (2011), Kegiatan fisik pada akhir pekan juga menurunkan ketegangan tubuh dengan cara merelaksasi otot dan mengurangi tingkat hormone stress seperti kortisol. 
Tabel 9. Korelasi Pearson Kelompok Aktivitas terhadap Pengaruh Positif di Senin pagi

\begin{tabular}{lccr}
\hline Kelompok Aktivitas & $\begin{array}{c}\text { Koefisien } \\
\text { Korelasi } \\
(\mathrm{R})\end{array}$ & $\alpha$ & $\begin{array}{c}\text { Signifikan } \\
\text { Pada } \alpha \leq 0,05 \\
(\text { Ya/Tidak?) }\end{array}$ \\
\hline Keagamaan & 0,091 & 0,132 & Tidak \\
Aktivitas Rumah & 0,014 & 0,434 & Tidak \\
Aktivitas Sosial & 0,127 & 0,058 & Tidak \\
Aktivitas Fisik & 0,190 & 0,009 & Ya \\
Pekerjaan & 0,164 & 0,121 & Tidak \\
Pendidikan & $-0,046$ & 0,285 & Tidak \\
Rekreasi & 0,222 & 0,003 & Ya \\
\hline
\end{tabular}

Untuk indikator pertanyaan pertimbangan yang akan mempengaruhi aktivitas akhir pekan, sebagian besar menjawab jarak tempuh dan durasi perjalanan yang paling berpengaruh. Sedangkan, seperti kerabat yang menemani beraktivitas dan juga beban pikiran yang paling tidak mempengaruhi. Dengan kata lain, seseorang akan tetap melaksanakan aktivitas yang sudah mereka rencanakan meskipun kerabat/anggota keluarga lainnya tidak dapat menemani beraktivitas. Begitu pula dengan beban pikiran, meski banyak hal yang sedang mereka pikirkan, seseorang akan tetap melaksanakan aktivitas akhir pekan mereka.

Tabel 10. Korelasi Pearson Kelompok Aktivitas terhadap Jarak Tempuh

\begin{tabular}{lccc}
\hline Kelompok Aktivitas & $\begin{array}{c}\text { Koefisien } \\
\text { Korelasi } \\
(\mathrm{R})\end{array}$ & $\alpha$ & $\begin{array}{c}\text { Signifikan } \\
\text { Pada } \alpha=0,05 \\
\text { (Ya/Tidak?) }\end{array}$ \\
\hline Keagamaan & 0,227 & 0,002 & Ya \\
Aktivitas Rumah & 0,207 & 0,005 & Ya \\
Aktivitas Sosial & 0,189 & 0,009 & Ya \\
Aktivitas Fisik & 0,269 & 0,000 & Ya \\
Pekerjaan & 0,323 & 0,000 & Ya \\
Pendidikan & $-0,139$ & 0,042 & Ya \\
Rekreasi & 0,211 & 0,004 & Ya \\
\hline
\end{tabular}

Tabel 11. Korelasi Pearson Kelompok Aktivitas terhadap Durasi Perjalanan

\begin{tabular}{lcrr}
\hline Kelompok Aktivitas & $\begin{array}{c}\text { Koefisien } \\
\text { Korelasi } \\
(\mathrm{R})\end{array}$ & $\alpha$ & $\begin{array}{c}\text { Signifikan } \\
\text { Pada } \alpha \leq 0,05 \\
\text { (Ya/Tidak?) }\end{array}$ \\
\hline Keagamaan & 0,048 & 0,276 & Tidak \\
Aktivitas Rumah & 0,248 & 0,001 & Ya \\
Aktivitas Sosial & 0,133 & 0,049 & Ya \\
Aktivitas Fisik & 0,238 & 0,001 & Ya \\
Pekerjaan & 0,215 & 0,004 & Ya \\
Pendidikan & $-0,050$ & 0,269 & Tidak \\
Rekreasi & 0,220 & 0,003 & Ya \\
\hline
\end{tabular}

Kemudian untuk penggunaan moda transportasi terbagi menjadi dua, yaitu kendaraan pribadi dan kendaraan umum. Untuk penggunaan kendaraan pribadi, mobil menjadi moda transportasi yang paling sering digunakan. Tetapi penggunaan motor juga tidak kalah banyak, untuk aktivitas dengan jarak yang tidak terlalu jauh, motor menjadi moda transportasi yang tepat.

Tabel 12. Rekapitulasi Jumlah Data Penggunaan Kendaraan Pribadi

\begin{tabular}{|c|c|c|}
\hline No & Indikator & $\mathrm{N}$ \\
\hline 1 & Berjalan kaki & 8 \\
\hline 2 & Sepeda & 1 \\
\hline 3 & Sepeda motor & 62 \\
\hline 4 & Mobil & 84 \\
\hline Total & & 155 \\
\hline
\end{tabular}


Sedangkan untuk penggunaan kendaraan umum, ojek online menjadi moda transportasi yang paling sering digunakan. Hal tersebut dikarenakan oleh ojek memiliki keunggulan dalam memangkas waktu tempuh perjalanan, melihat kotakota besar di JABODETABEK hampir semua ruas jalan ada kemacetan yang terjadi. Selain penggunaan ojek, kebanyakan setiap individu juga menggunakan bus untuk bermobilisasi.

Tabel 13. Rekapitulasi Jumlah Data Penggunaan Kendaraan Umum

\begin{tabular}{clc}
\hline No & \multicolumn{1}{c}{ Indikator } & $\mathrm{N}$ \\
\hline 1 & Ojek online / ojek konvensional & 42 \\
2 & Taksi online / taksi konvensional & 23 \\
3 & Bus (Busway, metromini, kopaja, dll) & 6 \\
4 & Angkutan kota & 1 \\
5 & KRL & 19 \\
6 & Ojek dan taksi & 23 \\
7 & Ojek dan Bus & 41 \\
\hline Total & & 155 \\
\hline
\end{tabular}

\section{KESIMPULAN}

Berdasarkan hasil penelitian yang dilakukan, maka didapati kesimpulan :

1. Berdasarkan data yang diterima, diketahui aktivitas yang paling sering dilakukan di setiap masing-masing kelompok aktivitas.

- $\quad$ Aktivitas rekreasi : pergi ke bioskop

- Aktivitas fisik : pergi ke tempat kebugaran

- Aktivitas keagamaan : pergi ke tempat ibadah

- Aktivitas sosial : pergi ke panti asuhan

- Aktivitas pendidikan : pergi ke kampus

- Aktivitas pekerjaan : pergi ke proyek/kantor

- $\quad$ Aktivitas rumah : berinternet.

2. Kendaraan pribadi yang mayoritas digunakan untuk menunjang aktivitas akhir pekan ialah mobil, karena mobil bisa mengangkut jumlah orang yang lebih banyak dalam satu kali perjalanan serta memberikan rasa nyaman. Sedangkan untuk penggunaan kendaraan umum yang paling sering digunakan adalah ojek online. Hal tersebut bisa dikarenakan oleh, kemudahan saat menggunakan, dan harga yang relatif terjangkau.

3. Waktu yang paling dikehendaki untuk beraktivitas akhir pekan adalah siang hari. Kebanyakan responden sudah melakukan aktivitas sesuai dengan waktu yang mereka kehendaki.

4. Aktivitas yang paling berpengaruh untuk mendapatkan afek positif pada senin pagi ialah aktivitas fisik (olahraga), dan aktivitas rekreasi.

\section{SARAN}

Saran yang dapat diberikan untuk pemanfaatan penelitian ini :

1. Agar seseorang dapat menggunakan waktu pada akhir pekan dengan lebih efisien, hendaknya membuat jadwal akhir pekan dari jauh-jauh hari, dengan begitu seseorang meminimalkan waktu yang terbuang. Hal tersebut akan berkaitan dengan menghidari kemacetan yang terjadi, karena JABODETABEK tidak terlepas dari kemacetan.

2. Menghilangkan beban pikiran pekerjaan maupun pendidikan, dapat dilakukan dengan melakukan aktivitas fisik dan rekreasi, karena berdasarkan data yang sudah saya terima, aktivitas fisik dan juga rekreasi memiliki peranan penting dalam menerima afek positif pada senin pagi.

Saran yang dapat diberikan untuk upaya pengembangan penelitian ini lebih lanjut antara lain:

1. Dikarenakan tidak ada perbedaan hasil antara pengumpulan data secara langsung dengan online, maka kedepannya disarankan menggunakan penyebaran kuesioner secara online, karena kuesioner online lebih mudah dan cepat dalam pengumpulan data.

2. Dengan dibangunnya infrastruktur baru di Jakarta, perlu ditambahkan pilihan penggunaan transportasi umum yang baru untuk menunjang aktivitas akhir pekan di penelitian berikutnya. 


\section{DAFTAR PUSTAKA}

Kamus Besar Bahasa Indonesia. [Online]. Tersedia di https://kbbi.web.id/transportasi. Diakses 27 Januari 2018.

------.-. Cara menghitung uji validitas dan uji reliabilitas dengan spss. Tersedia online di http://qmc.binus.ac.id/2014/11/01/u-j-i-v-a-l-i-d-i-t-a-s-d-a-n-u-j-i-r-e-l-i-a-b-i-l-i-t-a-s/. [Diakses tanggal 2 Februari 2019].

Bhat, C.R. dan Gossen, R. (2004). "A mixed multinomial logit model analysis of weekend recretional episode type choice". Transportation Research Part B, Vol. 38, 767-787.

Bhat, C.R. dan Sivaramakrishnan, S. (2005). "A multidimensional mixed ordered-response model for analyzing weekend activity participation”. Transportation Research Part B, Vol. 39, 255-278.

Bowersox, C. (1981). Introduction to Transportation. Macmillan Publishing Co, Inc, New York.

Cho, S. dan YoungAh, P. (2017). "How to Benefit form Weekend Physical Activities: Moderating Roles of Physicological Recovery Experience and Sleep". Stress and Health, 639-648.

Feuerhahn, N., Sonnentag, S., dan Woll, A. (2014). "Exercise After Work Psychological Mediator, and Effect: A DayLevel Study". European Journal of Work and Organizational Psychological, Vol. 23, 62-79.

Habib, K. (2010). “A Random Utility Maximization (RUM) Based Dynamic Activity Scheduling Model: Application in Weekend Activity Scheduling”. Transportation Vol. 38, 123-151.

Kleindorfer, P. R., Kunreuther, H. C., dan Schoemaker, P. (1993). Decisions Sciences: An Integrative Perspective. Cambridge University Press, Cambridge.

Krajewski, J., Sauerland, M., dan Wieland, R. (2011). "Relaxation-Induced Cortisol Changes within Lunch Breaks; An Experimental Longitudinal Worksite Field Study”. Journal of Occupational and Organizational Psychology, Vol. 84, 382-394.

Kudlacek, M. dan Fromel, K. (2016). "Compensation for Adolescents' School Mental Load by Physical Activity on Weekend Days". Environmental Research and Public Health, 1-12.

McMinn, A. M. dan Simon, J. G. (2012). "Family and Home Influences on Children's After-School and Weekend Physical Activity”. European Journal of Public Health Vol. 23, 805-810.

Miro, F. (2005). Perencanaan Transportasi untuk Mahasiswa, Perencana, dan Praktisi. Erlangga, Jakarta.

Nanda, N. N. (2013). Panduan Penyusunan Asuhan Keperawatan Profesional : Edisi Revisi Jilid 1 dan Jilid 2. Mediaction publishing.

Noonan, R. J. dan Stuart J. F. (2017). "Context Matters! Sources of Variability in Weekend Physical Activity Among Families: A Repeated Measures Study". BMC Public Health, 330-342.

Papacostas. (1987). Fundamentals of Transportation Enginering. Prantice Hall, USA.

Republik Indonesia. (1993). Ketetapan Presiden (Keppres) No. 22 Tahun 1993 Tentang Hak Karyawan atas Jaminan Sosial. Sekretariat Negara, Jakarta.

Republik Indonesia. (2000). Undang-Undang No. 21 Tahun 2000 Tentang Serikat Pekerja. Sekretariat Negara, Jakarta.

Republik Indonesia. (2003). Undang-Undang No. 13 Tahun 2003 Tentang Ketenagakerjaan. Sekretariat Negara, Jakarta.

Republik Indonesia. (2009). Undang-Undang No. 22 Tahun 2009 Tentang Lalu Lintar dan Angkutan Jalan. Sekretariat Negara, Jakarta.

Republik Indonesia. (Undang-Undang No. 32 Tahun 2009 Tentang Perlindungan dan Pengelolaan Lingkungan Hidup. Sekretariat Negara, Jakarta.

Siagian, S. P. (1990). Organisasi Kepemimpinan dan Perilaku Organisasi. Gunung Agung, Jakarta.

Simanjuntak, E. F. (2009). Analisa Pemilihan Moda Transportasi Bus, Angkutan Kota dan Kereta Api Rute Medan Tnajung Balai Terhadap Kenaikan Harga BBM. Departemen Teknik Sipil Fakultas Teknik Universitas Sumatera Utara, Medan.

Sonnentag, S. dan Fritz, C. (2015). "Recovery from Job Stress: The Stressordetachment Model as an Integrative Framework". Journal of Organizational Behavior, Vol 36, 72-103.

Steinberg, L. (1995). Adolescene Sanfrancisco. McGraw-Hill Inc.

Warpani, S. (1990). Merencanakan Sistem Perangkutan. Penerbit ITB, Bandung.

Yai, T. dan Yamada, H. (1995). "Nationwide Recreational Travel Survey in Japan: Outline and Modeling Applicability in Transportation Research Record". National Research Council, 29-38.

Zhong, M. dan Hunt, J. D. (2010). "Exploring Best-Fit Hazard Function and Lifetime Regression Models for Urban Weekend Activities: Case Study". Journal of Transportation Engineering, 255-266. 
